\title{
Placental Mesenchymal Dysplasia
}

National Cancer Institute

\section{Source}

National Cancer Institute. Placental Mesenchymal Dysplasia. NCI Thesaurus. Code C118161.

Aberrant mesenchymal cell growth within the placenta. It may be associated with Beckwith-Wiedemann Syndrome. 